Portland State University

PDXScholar

Engineering and Technology Management

Faculty Publications and Presentations

9-1-2016

\title{
Technology Readiness, Market Readiness and the Triple Bottom Line: An Empirical Analysis of Innovating Startups in an Incubator
}

Rainer Hasenauer

Hi-Tech Center

Andreas Gschöpf

INITS, Vienna Biocenter (VBC)

Charles Weber

Portand State University

Follow this and additional works at: https://pdxscholar.library.pdx.edu/etm_fac

Part of the Operations Research, Systems Engineering and Industrial Engineering Commons Let us know how access to this document benefits you.

\section{Citation Details}

Hasenauer, Rainer; Gschöpf, Andreas; and Weber, Charles, "Technology Readiness, Market Readiness and the Triple Bottom Line: An Empirical Analysis of Innovating Startups in an Incubator" (2016). Engineering and Technology Management Faculty Publications and Presentations. 106.

https://pdxscholar.library.pdx.edu/etm_fac/106

This Article is brought to you for free and open access. It has been accepted for inclusion in Engineering and Technology Management Faculty Publications and Presentations by an authorized administrator of PDXScholar. Please contact us if we can make this document more accessible: pdxscholar@pdx.edu. 


\title{
Technology Readiness, Market Readiness and the Triple Bottom Line: An Empirical Analysis of Innovating Startups in an Incubator
}

\author{
Rainer Hasenauer, Hi-Tech Center, Vienna, Austria \\ Andreas Gschöpf, INITS, Vienna Biocenter (VBC), Austria \\ Charles Weber, Portland State University, USA
}

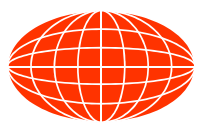

PICMET '16
September 4-8, 2016

Waikiki Beach Marriott

Honolulu, Hawai'i, USA

\section{Abstract}

This paper shares the experiences of INITS, a business incubator located in Vienna, Austria, which consults to startup firms in Austria and (with partners) in Europe. INITS has investigated the technology readiness levels and market readiness levels of 57 startup firms in a variety of industries, who are engaged in social or environmental entrepreneurship, where the impact motive prevails over the profit motive. Thus, INITS provides 57 longitudinal case studies of social and environmental innovation in startup firms that have gone through the complete incubation process. Thirteen of these cases underwent an 'open incubation' process developed by INITS.

INITS has learned a few important lessons from these endeavors. The open incubation method is more focused and streamlined than traditional methods. A formalized Web-based application process, as well as prolonged interaction with fellow startup firms and external experts, identify errors early, which accelerates incubation. Open incubation also achieves higher technology readiness levels and delivers lower technology risk, especially in the life sciences. Finally, open incubation is not restricted to startups that follow the triple bottom line. Applications for startups in multiple domains are possible. 


\section{Acknowledgements}

hi-tech center

i-tech center

No0092 ETC Projekt SR - AT

$\mathrm{HITECHZentrum} \mathrm{in} \mathrm{der} \mathrm{grenzuberschreitenden} \mathrm{Region}$

- The authors would like to thank the Hi-Tech Center in Vienna, Austria and INITS for sharing data that contributed to this paper

- The Hi-Tech Center

- is a multi-national, multi-regional industry-university partnership.

- funded by the European Union's fund for regional development and by various local government agencies.

- Members include the Technical University of Vienna; the Economics University of Bratislava and Vienna University of Economics and Business.

- The authors would also like to express their gratitude to Dr. Thomas Rusch and the Competence Center for Empirical Research Methods at WU (Vienna University of Economics and Business) for conducting the Mann-Whitney Test in Appendix F.

\section{Outline}

- Single versus Triple Bottom Line

- What is the impact on innovation in startup firms?

- Research Approach

- Technology Readiness versus Market Readiness

- Comparing incubation processes and industries

- Evidence from INITS

- Data from 57 companies

- act as longitudinal mini-cases.

- Lessons Learned

- Future Applications 
The Economics of High Tech Startups

- Single bottom line

- Maximize Return on Investment

Please see Appendix A for calculations.
Net Present Value and

Cumulative Return on

Cumulative Investment

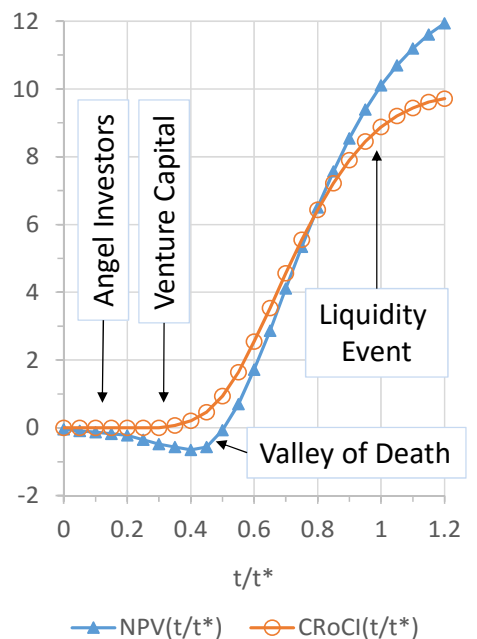

$\leftarrow \mathrm{NPV}\left(\mathrm{t} / \mathrm{t}^{*}\right)-\mathrm{CRoCl}\left(\mathrm{t} / \mathrm{t}^{*}\right)$

The Triple Bottom Line

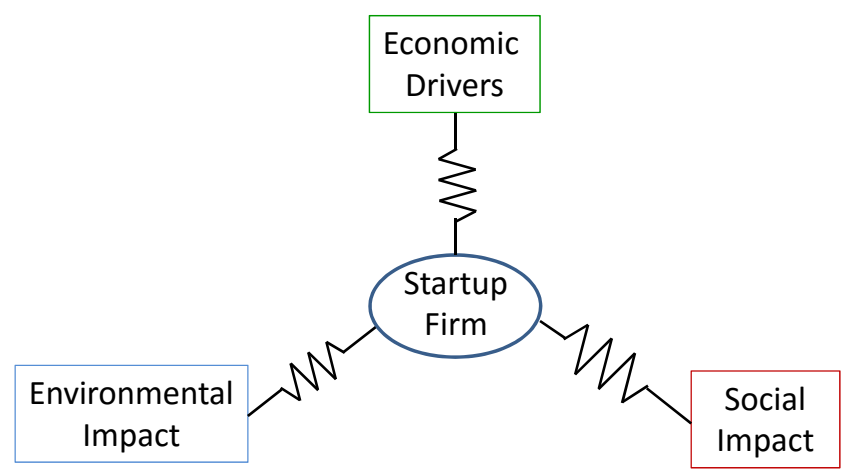

- Tradeoffs between economic drivers, environmental impact and social impact 


\section{Key Question}

Which incubation process is best suited for startup firms that are subjected to the triple bottom line?

\section{Approach}

- We share the experiences of INITS,

- a university business incubator in Vienna, Austria,

- which consults to startup firms

- in Austria and (with partners) in Europe.

- INITS

- has incubated 170 startup firms,

- including 57 startup firms

- engaged in social or environmental entrepreneurship,

- where impact motive prevails over profit motive.

- Ranked $3^{\text {rd }}$ in Europe ( $7^{\text {th }}$ world wide)

- among university business incubators

- in University Business Incubators (UBI) index [1] 


\section{Data Source}

- 57 longitudinal case studies

- of social and environmental innovation

- in startup firms that have gone through the complete incubation process.

- Sample includes

- Currently active and bought-out startups

- Merged startups and dissolved startups

- Startups use many different technologies.

\section{Research Method: Document Analysis}

- We look at all documents pertaining to incubation of every startup firm.

- Introduction documents

- Incubation application report

- Records of startup camp

- Records of team challenge

- Records of implementation plan

- Auditors' reports

- Milestone reports

- Incubation exit reports

- Alumni status report 


\section{Variables}

- Criteria: At each incubation milestone, we look at

- Technology Readiness Level (TRL)

- Market Readiness Level (MRL)

- Factors: We compare ...

- Two different incubation processes: $A$ and $B$

- Four industry types

- 6 milestones, 18 months of incubation

- See appendix E

\section{Criteria [2]-[10]}

- TRL - Technology Readiness Level (appendixes B \& C)

- expresses the degree of a technology

- to be used safely

- by intended and educated users

- in the envisaged commercial (market)

- or non-commercial user environment.

- MRL - Market Readiness level (appendixes B \& C)

- measures the maturity of a given need

- in the market considering

- the potential obstacles. 


\section{Criteria (continued)}

- We test for alignment between TRL and MRL during incubation process

- Measurement of readiness level is done by checking if the criteria used to describe the level are fulfilled.

- Criteria have been modified to reflect social and environmental context

\section{Measuring TRL/MRL ${ }_{[3]-[5]}$}

- Check if the criteria used to describe the respective level are fulfilled.

- Score reflects activity that has been completed.

- Definitions of TRL and MRL adapted to fit social and environmental (S/E) context.

- (For details, please see Appendix D) 


\section{Technology Readiness Levels $[3]-[7]$}

\section{More details in appendix D}

\begin{tabular}{|c|c|}
\hline Level & Social-Environmental-Technology Readiness Level \\
\hline $\mathbf{1}$ & Fundamental research in social / environmental context \\
\hline $\mathbf{2}$ & Applied research in social \& environmental context \\
\hline $\mathbf{3}$ & Research to prove social / environmental feasibility \\
\hline $\mathbf{4}$ & Social /environmental living lab demonstration \\
\hline $\mathbf{5}$ & S-Technology development \\
\hline $\mathbf{6}$ & Whole system field demonstration \\
\hline $\mathbf{7}$ & Socially \& environmentally compliant prototype \\
\hline $\mathbf{8}$ & Societal \& environmental technology acceptance \\
\hline $\mathbf{9}$ & Business model defined coherently \\
\hline $\mathbf{1 0}$ & Market / sales certification \\
\hline
\end{tabular}

\section{Market Readiness Levels [8], [9]}

More details in Appendix D

\begin{tabular}{|c|c|}
\hline Level & Social-Environmental--Market Readiness Level \\
\hline 1 & Unsatisfied needs have been identified \\
\hline 2 & Identification of potential social business opportunities \\
\hline 3 & System analysis and social environment impact analyzed \\
\hline 4 & Market research \\
\hline 5 & Target defined \\
\hline 6 & Industry analysis with respect to social and environmental impact \\
\hline 7 & Competitors analysis and positioning \\
\hline 8 & Value proposition defined \\
\hline 9 & Product/service defined \\
\hline 10 & Business model defined coherently $*$ \\
\hline
\end{tabular}

*Added by KIC InnoEnergy (see [10], p. 20) 


\section{System Rationality}

- Comprises economic \& social \& environmental rationality

- Document analysis and discussions with personnel at startup firms determine rationality.

- Startup included in sample, if ...

- Interdependence between economic, ecological and social factors is observed;

- Startup shapes its strategy for long term survival of the system.

- Startup is not out for fast profit!

- See Appendix D.5

\section{Focused, Streamlined Incubation:}

Stay on the Diagonal!

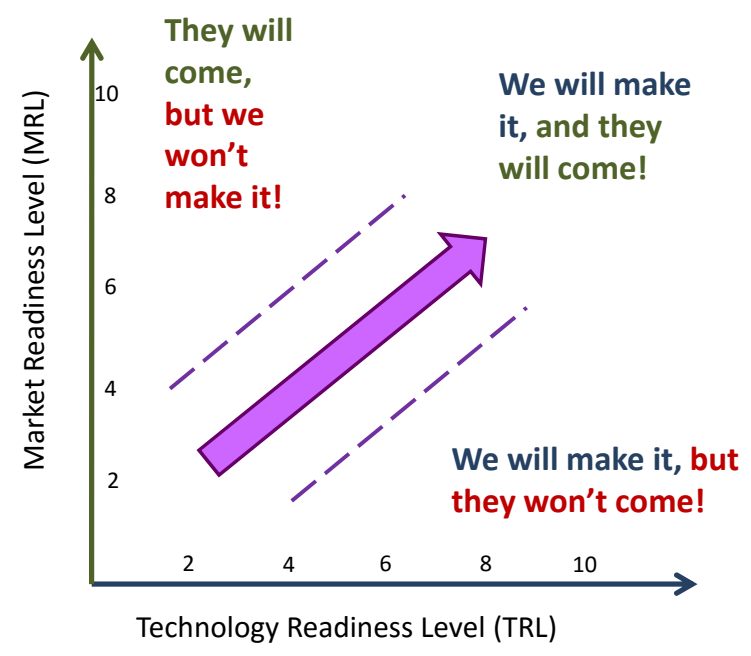

- Concurrent, step-by-step market and technology development places the right product into the right market window at the right time. 


\section{Risk Fields}

\begin{tabular}{|c|c|c|}
\hline & $\mathrm{TRL}<5$ & TRL $>5$ \\
\hline$M R L>5$ & $\begin{array}{l}\text { Market available, no } \\
\text { technology }=> \\
\text { MARKET RISK }\end{array}$ & $\begin{array}{l}\text { Market \& Technology } \\
\text { coherently mature }\end{array}$ \\
\hline$M R L<5$ & $\begin{array}{l}\text { Market \& Technology in } \\
\text { coherence, but not } \\
\text { mature }\end{array}$ & $\begin{array}{l}\text { Technology available, } \\
\text { No Market } \\
\text { TECHNOLOGY RISK }\end{array}$ \\
\hline
\end{tabular}

Technology Risk $\rightarrow$ focus on technology development Market Risk $\rightarrow$ focus on market development MISALIGNMENT BETWEEN MARKET AND TECHNOLOGY

\section{Two Sets of Candidate Factors}

- Open vs. closed incubation

- Four categories of industries

- Life Sciences (LS)

- Information Communication Technologies (ICT),

- ENVironmental Industries (ENV)

- Renewable energy, green traffic

- OTHer (OTH) e.g., materials science, robotics, mechatronic systems 


\section{Group A: "Open Incubation"}

- Incubation process developed at INITS

- from publicly available information

- "Digital introduction"

- Application for acceptance to incubator by website.

- Highly focused questions

- This allows a reliable and valid selection of start up applicants.

- "Startup Camp"

- Exchange of information between firms, external and internal experts

- Firms give feedback to each other, exchange experiences

- Education and training on the job

- Multiple startup firms work with each other in a group.

- Prolonged contact with external experts

- For more details, see appendix E.1

\section{Group B: "Closed Incubation"}

- Traditional method, mostly 1:1 communication

- No digital introduction

- Team challenge:

- Experts interview team members of startup.

- Conventional audits by incubator

- Milestone documentation: Have goals that have been agreed upon previously been met?

- Contact with other startups.

- Development more focused on internal experts

- Limited contact with external experts.

- For more details, see appendix E.2 


\section{Incubation Milestones}

Sample Group A

- AM1: Digital Introduction

- AM2: Project advisory board meeting

- AM3: Startup Camp

- AM4: milestone documentation, Implementation plan

- AM5: Incubation exit

- AM6: Alumni stage
Sample Group B

- BM1: First proposal

- BM2: Project advisory board meeting

- BM3: Team Challenge

- BM4: Auditing / milestone documentation, Implementation plan

- BM5: Incubation exit

- BM6: Alumni stage

\section{Dataset}

(For more details, please see Appendix E.)

Group A: Open Incubation

- 13 firms

- Incubation process A

- 4 Groups of Industries

- Feb. 2014 to Aug. 2015

- Ordinal data
Group B: Closed Incubation

- 44 firms

- Incubation process B

- 4 groups of industries

- Feb. 2007 to Nov. 2011

- Ordinal Data

\begin{tabular}{|c|c|c|c|c|c|c|}
\hline \multirow[b]{2}{*}{ Industry } & \multicolumn{2}{|c|}{ Incubation Process A } & \multicolumn{2}{|c|}{ Incubation Process B } & \multirow[t]{2}{*}{ Sum } & \multirow[t]{2}{*}{$\%$} \\
\hline & Sum & $\%$ & Sum & $\%$ & & \\
\hline LS & 4 & $31 \%$ & 11 & $25 \%$ & 15 & $26 \%$ \\
\hline ICT & 5 & $38 \%$ & 13 & $30 \%$ & 18 & $32 \%$ \\
\hline ENV & 2 & $15 \%$ & 8 & $18 \%$ & 10 & $18 \%$ \\
\hline ОТН & 2 & $15 \%$ & 12 & $27 \%$ & 14 & $25 \%$ \\
\hline Sum & 13 & $100 \%$ & 44 & $100 \%$ & 57 & $100 \%$ \\
\hline
\end{tabular}


Results-1:

Orderly, Streamlined Incubation

TRL corridor for all industries

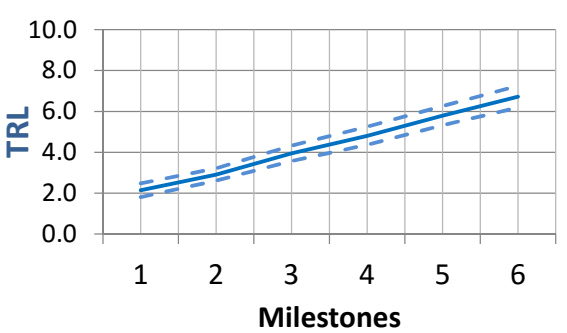

- MV TRL

- - MV - 0,25 MAD
MRL corridor for all industries

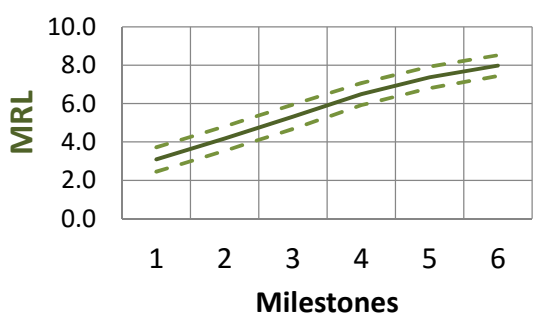

-MVMRL

$--M V+0,25 M A D$

- For process $A$ and for process $B$

- For TRL and for MRL

- Across all industries

\section{Results-2: $\boldsymbol{A}$ is better than $\boldsymbol{B}$}

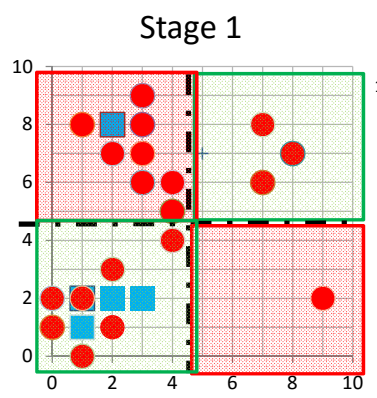

Stage 3

Stage 6
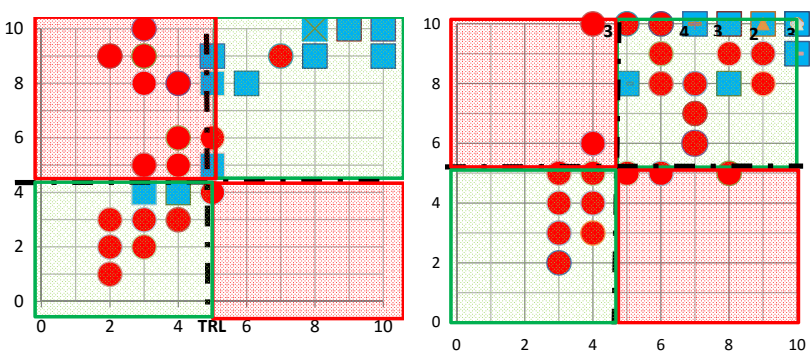

- A goes through accelerated incubation process.

- A reaches higher levels of TRL and MRL than $B$.

- Results are statistically significant.

- See Mann-Whitney test in Appendix F. 


\section{Results-3: Reduction of Technology Risk}

Final Results for Milestone 6

\begin{tabular}{|l|c|c|c|c|}
\hline MS6 & \multicolumn{2}{|c|}{ Type A } & \multicolumn{2}{c|}{ Type B } \\
\hline \multirow{2}{*}{$\mathrm{MRL}>5$} & 0 & 13 & 6 & 30 \\
\cline { 2 - 5 } & $0 \%$ & $100 \%$ & $14 \%$ & $68 \%$ \\
\hline \multirow{2}{*}{$\mathrm{MRL}<5$} & 0 & 0 & 8 & 0 \\
& $0 \%$ & $0 \%$ & $18 \%$ & $0 \%$ \\
\hline & $\mathrm{TRL}<5$ & $\mathrm{TRL}>5$ & $\mathrm{TRL}<5$ & $\mathrm{TRL}>5$ \\
\hline
\end{tabular}

Type A: (13 cases)

- No case with MRL < 5;

- No case with TRL $<5$.

- Not statistically significant

- Further cases to be examined in future
Type B: (44 cases)

- 0 cases with $\mathrm{MRL}<5 \& \mathrm{TRL}>5$

- 6 cases with MRL $>5$ \& TRL $<5$

- 5 of these cases in LS

-1 in ICT.

\section{Results-3: Industry-Specific Effects}

- Obtained through longitudinal analysis

- Not statistically significant

- But can be attributed to observable cause 


\section{Life Sciences (LS): A vs. B}
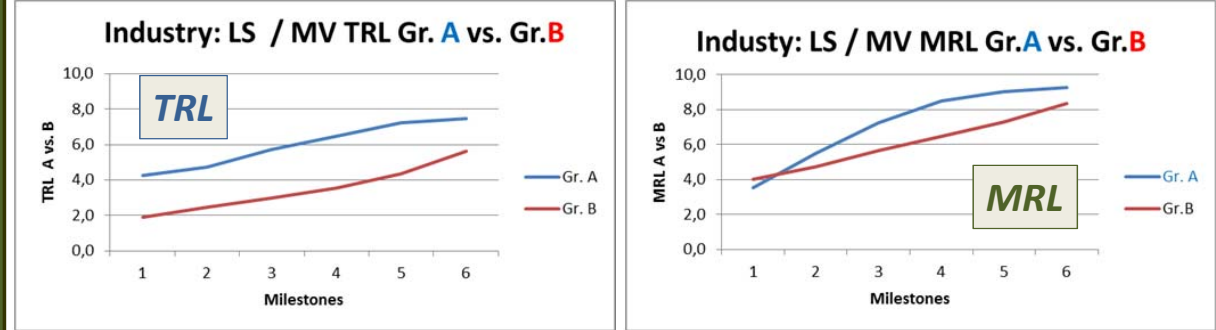

- TRL for $A$ ahead of TRL for $B$

- Digital entry forces startups to focus.

- $B$ never reaches TRL that $A$ does

- No market risk for $A$ or $B$

\section{Life Sciences (LS): A vs. B}
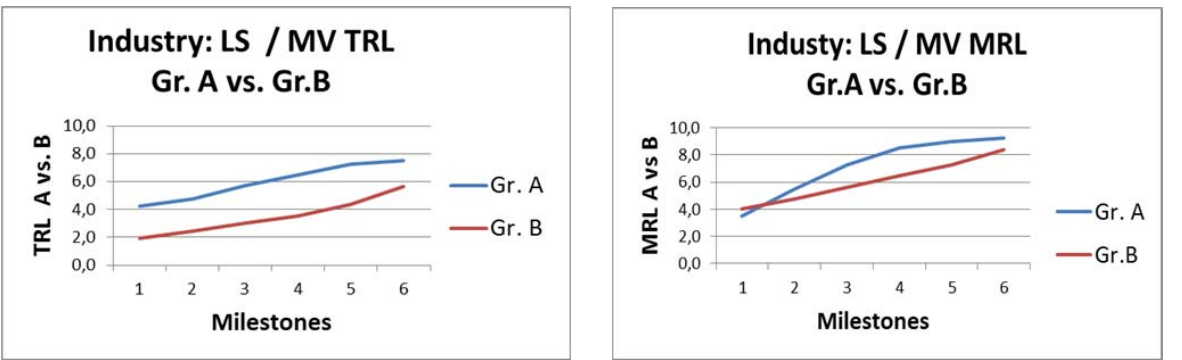

- TRL for $A$ ahead of TRL for $B$

- Digital entry forces startups to focus.

- $B$ never reaches TRL that $A$ does

- No market risk for $A$ or $B$ 


\section{Information/Communication Technology} (ICT): $A$ vs. $B$
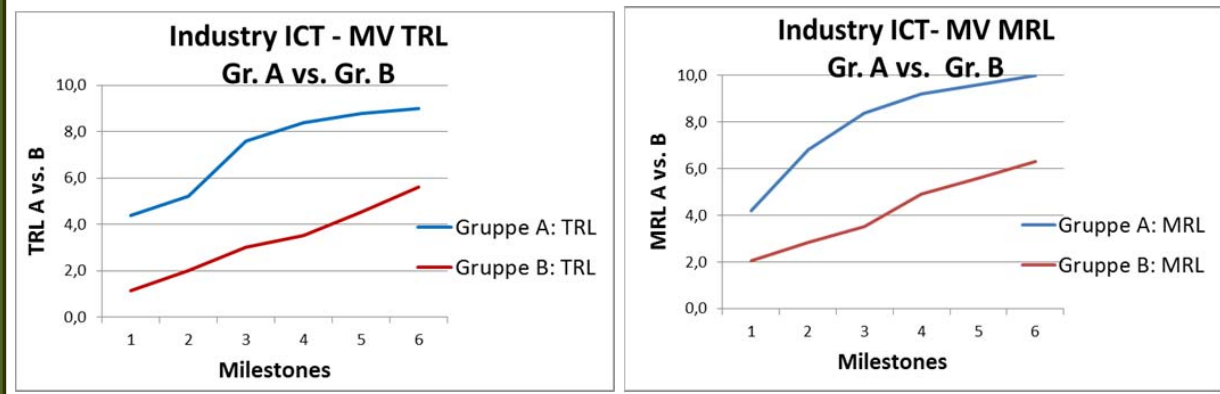

- MRL and TRL faster for $A$ than for $B$

\section{Information/Communication Technology (ICT): A vs. B}

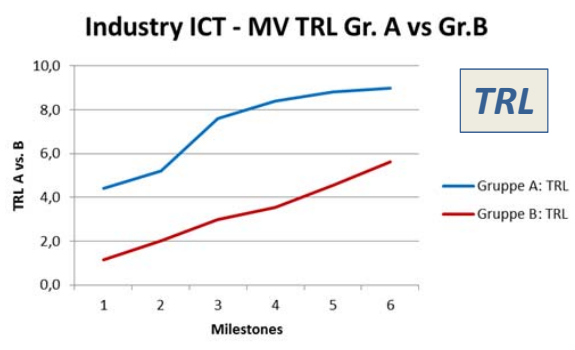

Industry ICT- MV MRL Gr.A vs. Gr. B

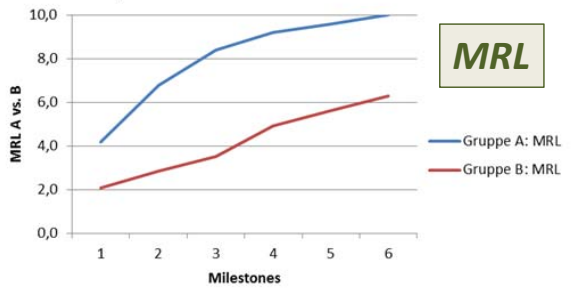

- MRL and TRL faster for $A$ than for $B$ 


\section{Lessons Learned}

1. Both $A$ and $B$ offer consistent guidelines for triple bottom line innovation management.

- Approach may be generalizable to all startups

- Needs to be demonstrated by further research

2. Open Incubation approach $(A)$ more focused and streamlined

- Lower technology risk, especially in life sciences

- $A$ faster than $B$ in many instances

\section{Lessons Learned (continued)}

3. Digital Introduction, Pre-incubation and

Startup Camps

- identify errors early

- and cause temporary setbacks,

- but accelerate incubation overall

4. Implementation:

- Further education of startup teams in technology acceptance and marketability criteria is required. 


\section{Implications:}

\section{Recommendations from INITS}

- Startup firms and their incubators

- should conduct longitudinal studies

- of technological and market readiness

- early on.

- These will allow the firms to adjust their metrics

- to the meet the requirements

- of the triple bottom line

- without incurring significant

- additional technology and market risk.

\section{Future Applications}

- Open incubation

- may be the wave of the future

- for all kinds of startups,

- not for just those

- that follow the triple bottom line.

- More research needed! 


\section{Upcoming Activities}

- In depth investigation of triple bottom line

- Tradeoffs between profit, social and environmental

- Expand research to startups of all kind

- Sample of 170 startups is available.

- New startups are entering INITS.

- In depth investigation of industry-specific effects

- May enable approaches that are customized to specific industries.

Thank you for your attention!

\section{QUESTIONS AND ANSWERS}




\section{References (1)}

[1] Universal Business Incubators Global, UBI-Global Index, available online at www.ubi-global.com, retrieved January 12, 2016.

[2] M. Biegl, R. Hasenauer, et al., "Marketing testbeds for high tech innovation: The case of Taurob Robotics," Proceedings of PICMET '14, Kanazawa, Japan, July 27 - 31, 2014, pp. 1145-1168.

[3] R. Hasenauer, C. M. Weber, P. Filo and J. Jozef Orgonáš, "Managing technology push through marketing testbeds: The case of the Hi Tech Center in Vienna, Austria," Proceedings of PICMET '15, Portland, Oregon, USA, Aug. 2-6, 2015, pp. 99-126.

[4] D. Dent and B. Pettit, "Technology and Market Readiness Levels.," (White Paper) Dent Associates 2011

[5] R. Valerdi and R. J. Kohl, "An Approach to Technology Risk management," presented at Engineering Systems Division Symposium, MIT , Cambridge, MA, USA, March 29-31, 2004.

[6] J. C. Mankins, "Technology Readiness Levels," (White Paper) ,Advanced Concepts Office, Office of Space Access and Technology, NASA, April 6, 1995.

[7] European Association of Research and Technology Organisations (EARTO), "The TRL Scale as a Research \& Innovation."

[8] F. Paun, "Demand readiness Level (DRL), a new tool to hybridize Market Pull and Technology Push approaches.," presented at A NR-ERANET Workshop, Paris, France, Feb. 2011.

\section{References (2)}

[9] B. J. Sauser, J.E.Ramirez-Marquez, H. Devanandham and D. DiMarzio, "A system maturity index for the systems engineering lifecycle ," International Journal of Industrial and Systems Engineering, Vol. 3, No. 6, 2008, pp. 1-31.

[10] C. Jullien, "Considerations for an innovation readiness level along with the 'Technology and Manufacturing Readiness Level' indicators," IEA Committee on Energy Research and Technology - Modelling and Analyses in R\&D Priority Setting an Innovation, KIC InnoEnergy meeting, Paris, France, April $23-24,2014$, pp. 2-25.

[11] C.M. Weber and J. Yang, "Organizational learning and capital productivity in semiconductor manufacturing," IEEE Transactions on Semiconductor Manufacturing, Vol. 27, No. 3, August 2014, pp. 316-326.

[12] U. E. Reinhardt, "Break-even analysis for Lockheed's Tri Star: An application of financial theory," The Journal of Finance, Vol. 28, No. 4, September, 1973, pp. 821-838.

[13] H. Jander, J. Borgvall and R. Ramberg, "Towards a methodological framework for HMI Readiness Evaluation," Proceedings of the Human Factors and Ergonomic Society, 56th Annual Meeting, Sept. 2012, Vol. 56, No. 1, pp. 2349-2354

[14] T. Lan, "Developing the Concept - Innovation Readiness Levels ," technical report , Center of Technology Management, Univ. of Cambridge, UK, 2010

[15] KTH Royal Institute of Technology, Stockholm: Innovation support system, 2012. 


\section{About the Authors}

- Rainer Hasenauer is an entrepreneur, a program manager at the Hi-Tech Center and an honorary professor at the Vienna University for Economics and Business, Austria.

- Andreas Gschöpf is senior technologist at INITS, a business incubator in Vienna, Austria.

- Charles Weber is an associate professor of engineering and technology management at Portland State University, USA.

\section{Appendix A: Net Present Value and Return on Investment [11]}

$$
\begin{aligned}
& \operatorname{NPV}(\mathrm{t})=\int_{0}^{\mathrm{t}}[\mathrm{R}(\mathrm{t})-\mathrm{C}(\mathrm{t})] \mathrm{e}^{-\rho t} d t \quad[12, \mathrm{p} .822] \\
& \mathrm{CRoCI}(\mathrm{t})=\underset{0}{\left\{\int_{0}^{\mathrm{t}} \mathrm{R}(\mathrm{t}) \mathrm{e}^{-\rho t} \mathrm{dt}\right\}} \underset{0}{\left\{\int_{0}^{\mathrm{t}} \mathrm{C}(\mathrm{t}) \mathrm{e}^{-\rho \mathrm{t}} \mathrm{dt}\right\}}
\end{aligned}
$$

$R(t)=$ Revenue Generation Rate; $C(t)=$ Cash Outlay rate $\mathrm{t}=$ time since venture inception; $\mathrm{t}_{0}=$ time of liquidity event The continuously compounded discount rate $\rho=\ln (1+K)$; $\mathrm{K}=$ corporation's effective annual cost-of-capital rate; $\mathrm{e}^{-\mathrm{et}}=$ discount rate; $N P V(t)=$ Net Present Value

$\mathrm{CRoCl}(\mathrm{t})=$ Cumulative Return on Cumulative Investment 
Additional Explanation of TRL \& MRL

\section{APPENDIX B [3]}

Appendix B: Technology Readiness Level (TRL)

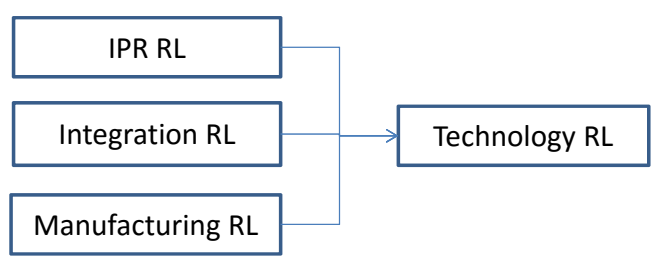

- Consists of three components:

- Intellectual property readiness

- Has IP been protected?

- Does the firm have the right to operate without restrictions?

- Integration readiness

- Can technologies be integrated?

- Manufacturing readiness

- Can product be manufactured? 


\section{Appendix B:}

\section{Clarification of Additional Terms [3]-[8]}

- MFRL - Manufacture Readiness Level

- identifies the preparedness of the manufacturer

- to develop the manufacturing process

- and to assess the risk and feasibility

- of a given technology.

- IRL--Integration Readiness Level

- describes the difficulties

- of progressing through TRL scale

- and choosing between / combining

- competing alternative technologies.

- IPR RL - Intellectual Property Right Readiness Level

- Covers issues such as patenting, research agreements and collaboration agreements that impact IP ownership.

Appendix B:

Market

Readiness

Level (MRL)

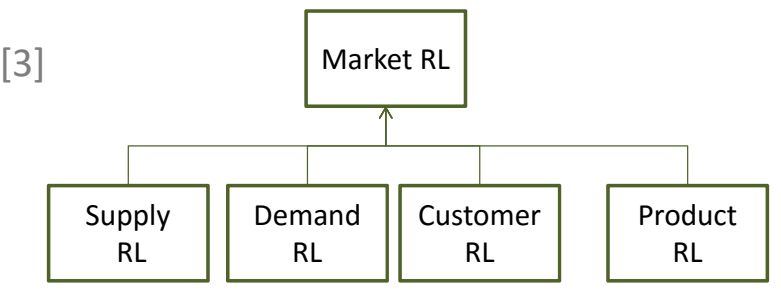

- Consists of four components:

- Supply readiness

- To what degree are competitors' products available?

- Demand readiness

- What is the demand for the product?

- Customer readiness

- Is the customer ready to use and adopt the product?

- Product readiness

- Is the product ready for widespread use? 
Readiness Levels

APPENDIX C $[3]$

\title{
Integration Readiness Levels
}

\author{
[3], [9], [10], [13]
}

\section{Level Action Performed}

$1 \quad$ An Interface between technologies has been identified with sufficient detail to allow characterization of the relationship

2 There is some level of specificity to characterize the Interaction (i.e. ability to influence) between technologies through their interface.

3 There is compatibility (i.e. common language) between technologies to orderly and efficiently integrate and interact

4 There is sufficient detail in the quality and assurance of the integration between technologies.

5 There is sufficient control between technologies necessary to establish, manage, and terminate the integration

6 The integrating technologies can accept, translate, and structure information for its intended application.

7 The integration of technologies has been verified and validated with sufficient detail to be actionable.

8 Actual integration completed and mission qualified through test and demonstration, in the system environment.

9 Integration is mission proven through successful mission operations. 


\section{Innovation Readiness Levels [14]}

- Innovation Readiness Level (IRL) expresses the readiness of an organization to implement and safely use an innovation by intended and educated user.

TRL 1 Basic principles observed and reported

Concept

TRL 2 Technology concept and/or application formulated

TRL 3 Analytical and experimental critical function and/or characteristic proof-of-concept TRL 4 Component and/or breadboard validation in laboratory environment

TRL 5 Component and/or breadboard validation in relevant environment

TRL 6 System/subsystem or prototype demonstration in a relevant environment (ground or space) TRL 7 System prototype demonstration in a space environment

TRL 8 Actual system completed and "flight qualified" through test and demonstration

TRL 9 Actual system "flight proven" through successful mission operations

\section{Completion}

\section{Intellectual Property Readiness Level}

\section{Level Action performed}

$1 \quad$ Hypothesizing on possible IPR (patentable inventions)

2 Identified specific patentable inventions or other IPR

3 Detailed description of possible patentable inventions. Initial search of the technical field and prior art.

$4 \quad$ Confirmed novelty and patentability; decided on alternative IP protection if not patenting

5 First complete patent application filed, Draft of IPR strategy done.

6 Positive response on patent application; initial assessment of freedom to operate, patent strategy supporting business

$7 \quad$ Patent entry into national phase; other formal IPR registered

8 First patent granted, IPR strategy fully implemented, more complete assessment of freedom to operate

9 Patent granted in relevant countries, strong IPR support for business 
Readiness Levels

in the Social/Environmental Context

APPENDIX D

\section{Appendix D.1: Social/Environmental Technology Readiness Level}

\begin{tabular}{|c|c|}
\hline Level & Social-Environmetnal-Technology Readiness Level \\
\hline $\mathbf{1}$ & Fundamental research in social / environmental context \\
\hline $\mathbf{2}$ & Applied research in social \& environmental context \\
\hline $\mathbf{3}$ & Research to prove social / environmental feasibility \\
\hline $\mathbf{4}$ & Social /environmental living lab demonstration \\
\hline $\mathbf{5}$ & S-Technology development \\
\hline $\mathbf{6}$ & Whole system field demonstration \\
\hline $\mathbf{7}$ & Socially \& environmentally compliant prototype \\
\hline $\mathbf{8}$ & Societal \& environmental technology acceptance \\
\hline $\mathbf{9}$ & Market / sales certification \\
\hline $\mathbf{1 0}$ & Business model defined coherently \\
\hline
\end{tabular}




\section{Appendix D.2: Social/Environmental Market Readiness Level}

\begin{tabular}{|c|c|c|c|}
\hline & Market Readiness Level & & S/E Market readiness Level \\
\hline 1 & Unsatisfied needs identified & 1 & Unsatisfied needs identified \\
\hline 2 & $\begin{array}{l}\text { Identification of the potential } \\
\text { business opportunities }\end{array}$ & 2 & $\begin{array}{l}\text { Identification of potential S/E business } \\
\text { opportunities }\end{array}$ \\
\hline 3 & $\begin{array}{l}\text { System analysis and general } \\
\text { environment analyzed }\end{array}$ & 3 & $\begin{array}{l}\text { System analysis and S/E environment } \\
\text { impact analyzed }\end{array}$ \\
\hline 4 & Market research & 4 & Market research \\
\hline 5 & Target defined & 5 & Target defined \\
\hline 6 & Industry analysis & 6 & Industry analysis \\
\hline 7 & Competitors analysis and positioning & 7 & Competitors analysis and positioning \\
\hline 8 & Value proposition defined & 8 & Value proposition defined \\
\hline 9 & Product/service defined & 9 & Product /service defined \\
\hline 10 & Business model defined coherently & 10 & Business model defined coherently \\
\hline
\end{tabular}

\section{Appendix D.3: Technology Acceptance $[x \times]$ and Social/Environmental Innovation}

\begin{tabular}{|l|l|l|l|l|}
\hline No. & Parameter & Social context & Modified parameter & Example \\
\hline $\mathbf{1}$ & Perceived Usefulness & $\begin{array}{l}\text { Perceived S/E } \\
\text { Usefulness }\end{array}$ & $\begin{array}{l}\text { Collision avoidance } \\
\text { for blind persons }\end{array}$ \\
\hline $\mathbf{2}$ & Perceived Ease of Use & $\begin{array}{l}\text { target group in the } \\
\text { social market }\end{array}$ & $\begin{array}{l}\text { Perceived social ease } \\
\text { of use by increased } \\
\text { participation and } \\
\text { inclusion }\end{array}$ & $\begin{array}{l}\text { Mobile PV cases and } \\
\text { rechargeable } \\
\text { batteries for selling } \\
\text { electricity in remote } \\
\text { area }\end{array}$ \\
& & &
\end{tabular}




\section{Appendix: D.4: Marketability Criteria for Technology Based S/E Innovation}

\begin{tabular}{|c|c|c|c|c|}
\hline MC & Content & Social Context & Modification & Comment \\
\hline 1 & Innovative & \multirow{3}{*}{$\begin{array}{l}\text { Relative to target group's } \\
\text { knowledge \& experience }\end{array}$} & \multirow{3}{*}{$\begin{array}{l}\text { Innovative } \\
\text { feature/function is } \\
\text { S/E innovative, } \\
\text { testable and } \\
\text { controllable } \\
\text { by target group }\end{array}$} & $\begin{array}{l}\text { New degrees of freedom } \\
\text { New chances of welfare }\end{array}$ \\
\hline 2 & Testable & & & $\begin{array}{l}\text { New knowledge and } \\
\text { willingness to explore by } \\
\text { trial and error }\end{array}$ \\
\hline 3 & controllable & & & $\begin{array}{l}\text { New challenge to trust } \\
\text { technology }\end{array}$ \\
\hline 4 & $\begin{array}{l}\text { Compatible to } \\
\text { industrial and social } \\
\text { standards }\end{array}$ & \multirow{3}{*}{$\begin{array}{l}\text { To law and cultural } \\
\text { standards of target group }\end{array}$} & $\begin{array}{l}\text { Compatible to } \\
\text { industrial and } \\
\text { social standards of } \\
\text { target group }\end{array}$ & $\begin{array}{l}\text { At least minimum } \\
\text { required matching to } \\
\text { societal standards of the } \\
\text { addressed target group }\end{array}$ \\
\hline 5 & implementable & & $\begin{array}{l}\text { Implementable in } \\
\text { compliance with } \\
\text { social standards }\end{array}$ & \\
\hline 6 & assimilative & & $\begin{array}{l}\text { Social innovation } \\
\text { is assimilated by } \\
\text { target group }\end{array}$ & \\
\hline
\end{tabular}

\section{Appendix D.5}

\section{Triple Bottom Line - System Rationality}

\begin{tabular}{|l|l|l|l|}
\hline \multicolumn{1}{|c|}{$\begin{array}{c}\text { SYSTEM } \\
\text { RATIONALITY }\end{array}$} & \multicolumn{1}{|c|}{ ECONOMY } & \multicolumn{1}{|c|}{ SOCIAL } & \multicolumn{1}{c|}{ ECOLOGICAL } \\
\hline Max. Output & $\begin{array}{l}\text { Max. RoS! } \\
\text { With given } \\
\text { capacity }\end{array}$ & $\begin{array}{l}\text { Max. social welfare! } \\
\text { With given social } \\
\text { budget }\end{array}$ & $\begin{array}{l}\text { Max. ecological } \\
\text { compliance } \\
\text { With given } \\
\text { ecological budget }\end{array}$ \\
\hline Given Output & $\begin{array}{l}\text { Given RoS } \\
\text { with min. Input } \\
\text { of capacity }\end{array}$ & $\begin{array}{l}\text { Given social welfare } \\
\text { with min. Input of } \\
\text { social budget }\end{array}$ & $\begin{array}{l}\text { Given degree of } \\
\text { ecological } \\
\text { compliance with } \\
\text { min. Input } \\
\text { budget }\end{array}$ \\
\hline
\end{tabular}

RoS: Return on Sales 


\section{Comparing Incubation Processes}

\section{APPENDIX E}

\section{Appendix E.1: Sample Group A}

- Recently founded startups

- All passed through digital introduction phase.

- Started February/March 2014

- End of incubation process on Aug, 31, 2015.

- Duration for one incubation cohort: 18 months.

- Milestones:

- AM1 Introduction

- AM2 Project advisory board meeting

- AM3 Startup camp

- AM4 Implementation plan / partly with team challenge

- AM5 Incubation exit

- AM6 Alumni stage 
Appendix E.1:

Open Incubation (Process $\boldsymbol{A}$ )

\begin{tabular}{|ll|l|l|l|} 
DIGITAL INTRO & PAB & SUC & IMPL (TC/MS) INC EX & ALUM stage
\end{tabular}

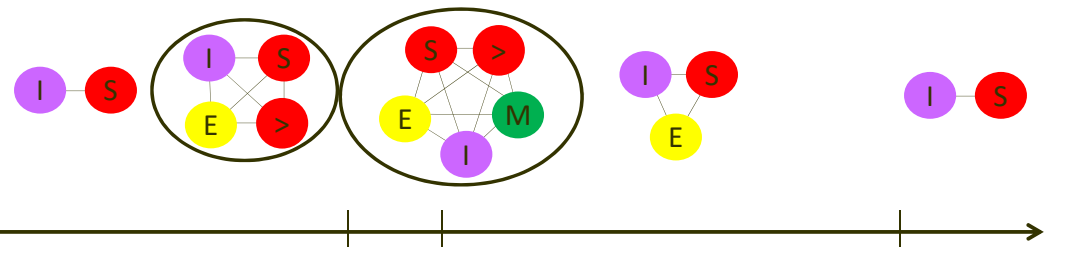

Start-up S Start-ups

PAB Project advisory board

SUC Start Up Camp , TC Team Challenge
Market Feedback M External Expert $E$

External Advisors, Internal Experts

MS milestone INC EX Incubator Exit

\section{Appendix E.2: Sample Group B}

- Prior Startups:

- no digital introduction phase,

- all passed through the incubator,

- all of them passed the team challenge,

- partially with auditing operation and/or milestone documentation.

- From February 2007 until end of incubation on Nov. 1, 2011

- Milestones:

- BM1 First proposal

- BM2 Project advisory board meeting

- BM3 Team challenge

- BM4 Auditing / milestone documentation

- BM5 Incubation exit

- BM6 Alumni stage 
Appendix E.2:

Closed Incubation (Process B)

\begin{tabular}{|ll|l|ll|l|} 
FIRST PROPOSAL & PAB & TC & IMPL (AUDIT/MS) & INC EX & ALUM
\end{tabular}
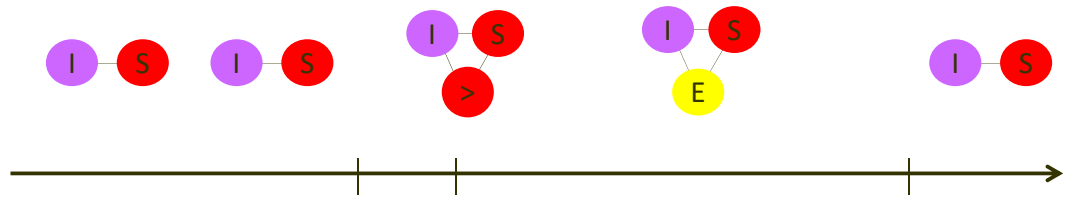

Start-up S Start-ups

Market Feedback M External Expert E

PAB Project advisory board External Advisors, Internal Experts

SUC Start Up Camp , TC Team Challenge MS milestone INC EX Incubator Exit

\section{Mann-Whitney Test* APPENDIX F}

\footnotetext{
*Performed by Thomas Rusch, statistician at Wirtschaftsuniversitaet Wien
} 


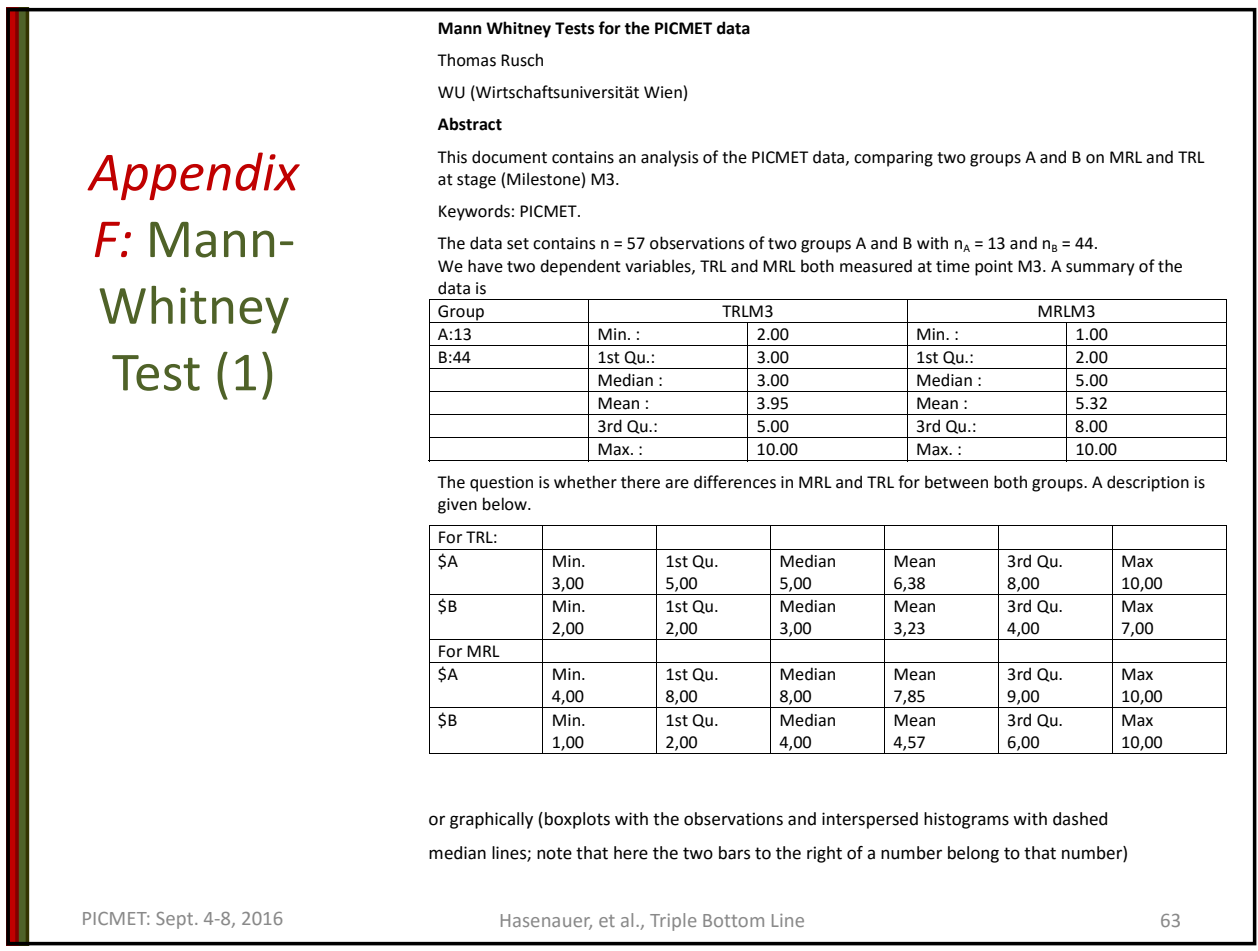

Appendix

F: Mann-

Whitney

Test (2)
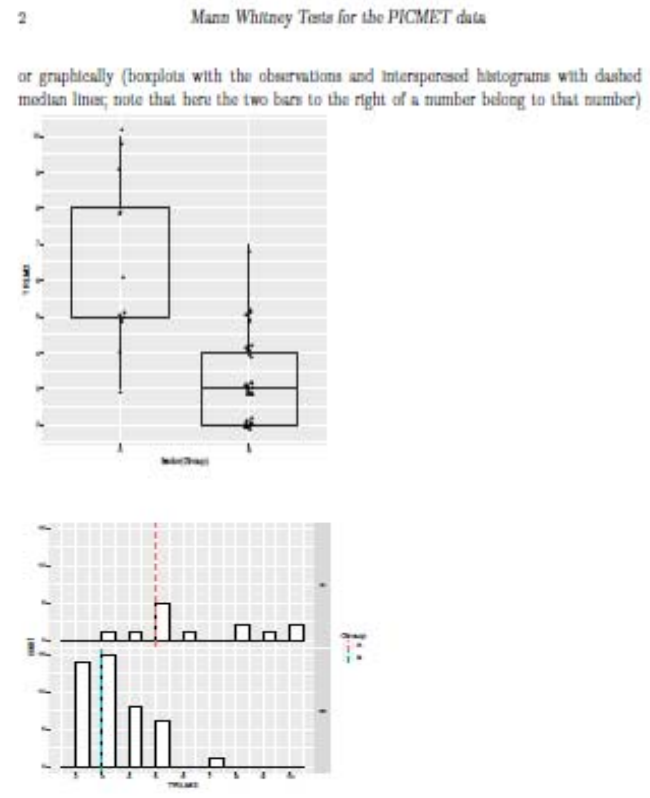
Appendix F: MannWhitney Test (3)

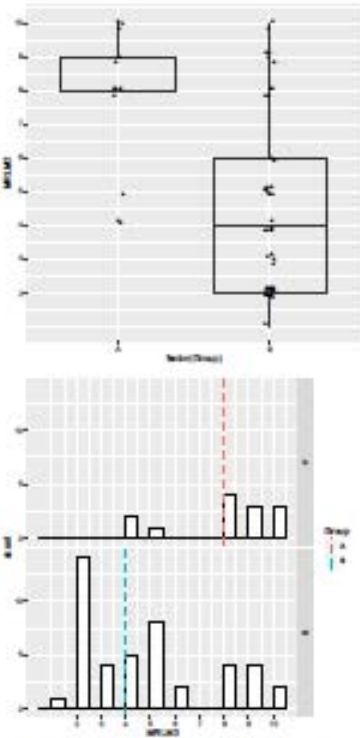

We test for differeness in the datritution function of the two groups with the Mann-Whitney. Wilcuxon test. This as mostly a test for ahtif in locatoon but will have some power anduat the

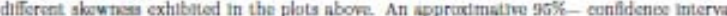
for the bestion diffirences is abo printed.

\section{Appendix F: Mann-Whitney Test (4)}

Wilcoxon rank sum test with continuity correction

Data: TRLM3 by Group

$\mathrm{W}=520, \mathrm{p}$-value $=7 \mathrm{e}-06$

Alternative hypothesis: true location shift is not equal to 0

95 percent confidence interval:

$$
24
$$

Sample estimates: difference in location 4

Mann Whitney Tests for the PICMET data

$\mathrm{R}>$ wilcox.test(MRLM3 Group, picmet, conf.int=TRUE)

Wilcoxon rank sum test with continuity correction

data: MRLM3 by Group

$\mathrm{W}=460, \mathrm{p}$-value $=6 \mathrm{e}-04$

Alternative hypothesis: true location shift is not equal to 0

95 percent confidence interval:

$-\frac{2}{2}-\frac{6}{\text { sample estimates: difference in location }}$

In both cases (TRL at M3 and MRL at M3) we have a significant location difference (which is the median of differences of a sample from group $A$ and group B) at $\alpha=0: 05$, so we reject the null hypothesis of equal location for both groups. The observed location differences are 3 (with $95 \%$ confidence interval (CI) of $[2,4])$ for TRL and $4(\mathrm{Cl}=[2,6])$ for MRL. We dare say that group A shows both higher TRL and MRL I levels at M3 (with approximate $p$-values of 0.000007 for TRL and 0.0006 for MRL).

PICMET: Sept. 4-8, $2016---------------------\frac{-1}{66}$ 
Appendix F: Test results for all Milestones

Mann-Whitney Test (5)

\begin{tabular}{|c|c|c|c|c|c|c|}
\hline \multirow[b]{2}{*}{ TRL } & \multicolumn{6}{|c|}{ MILESTONES } \\
\hline & MS1 & MS2 & MS3 & MS4 & MS5 & MS6 \\
\hline Sum & 567,5 & 584,5 & 608,5 & 602,5 & 590,5 & 521 \\
\hline Expect & 377 & 377 & 377 & 377 & 377 & 377 \\
\hline StdErr & 52,5800976 & 52,5800976 & 52,5800976 & 52,5800976 & 52,5800976 & 52,5800976 \\
\hline Teststat & 3,62304386 & 3,94636011 & 4,40280658 & 4,28869497 & 4,06047173 & 2,73867883 \\
\hline $\mathrm{p}$ & 0,00029116 & $7,9348 \mathrm{E}-05$ & $1,0686 \mathrm{E}-05$ & $1,7973 \mathrm{E}-05$ & $4,8974 \mathrm{E}-05$ & 0,00616866 \\
\hline \multirow[t]{2}{*}{ TRL: } & \multicolumn{6}{|c|}{$\begin{array}{l}\text { Incubation process A is significantly more efficient in all milestones } \\
\text { than process B }\end{array}$} \\
\hline & \multicolumn{6}{|c|}{ MILESTONES } \\
\hline MRL & MS1 & MS2 & MS3 & MS4 & MS5 & MS6 \\
\hline Sum & 487 & 520,5 & 555 & 578 & 548,5 & 509 \\
\hline Expect & 377 & 377 & 377 & 377 & 377 & 377 \\
\hline StdErr & 52,5800976 & 52,5800976 & 52,5800976 & 52,5800976 & 52,5800976 & 52,5800976 \\
\hline Teststat & 2,09204632 & 2,72916952 & 3,38531133 & 3,82273919 & 3,26169041 & 2,51045559 \\
\hline $\mathrm{p}$ & 0,03643437 & 0,00634941 & 0,00071098 & 0,00013198 & 0,0011075 & 0,01205755 \\
\hline MRL: & \multicolumn{6}{|c|}{$\begin{array}{l}\text { Incubation process A is significantly more efficient in all milestones } \\
\text { than process B }\end{array}$} \\
\hline
\end{tabular}

Longitudinal Analysis

Industry-Specific Phenomena

\section{APPENDIX G}


Stage 6: Numerical results per industry for TRL / MRL
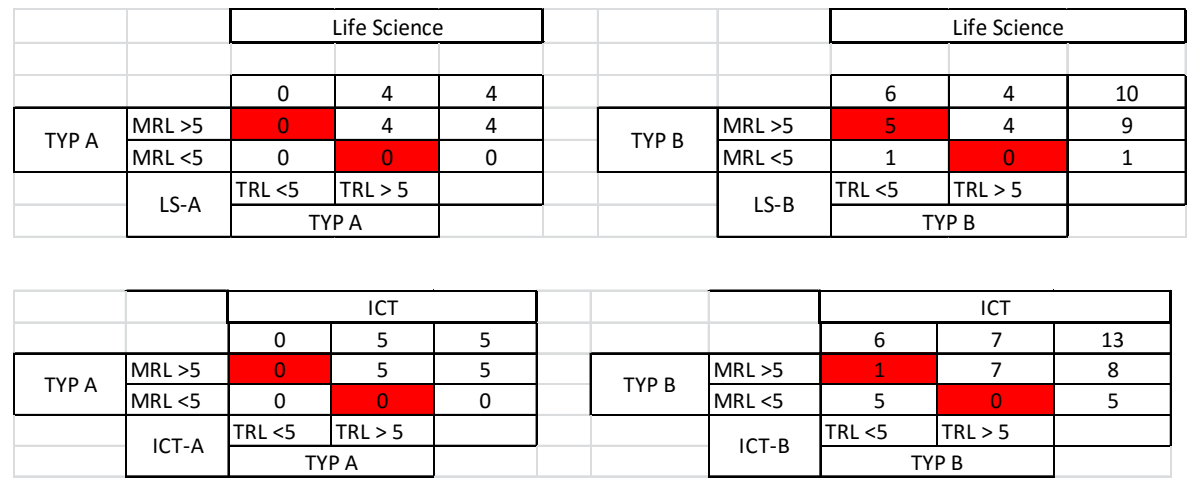

Stage 6: Numerical results per industry for TRL / MRL
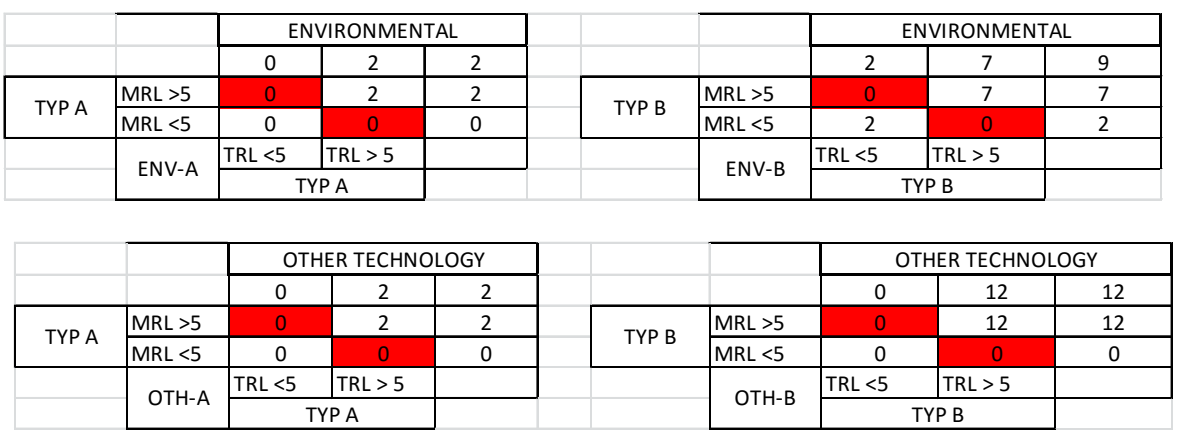


\section{Difference in Incubation Process in terms of TRL and MRL}

- Life Science:
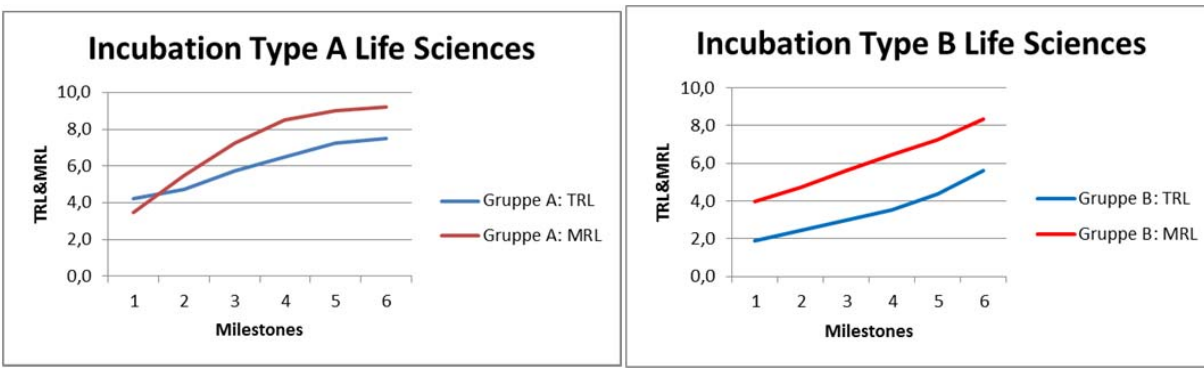

Longitudinal analysis

Difference in Incubation Process A and B in terms of mean values of TRL and MRL
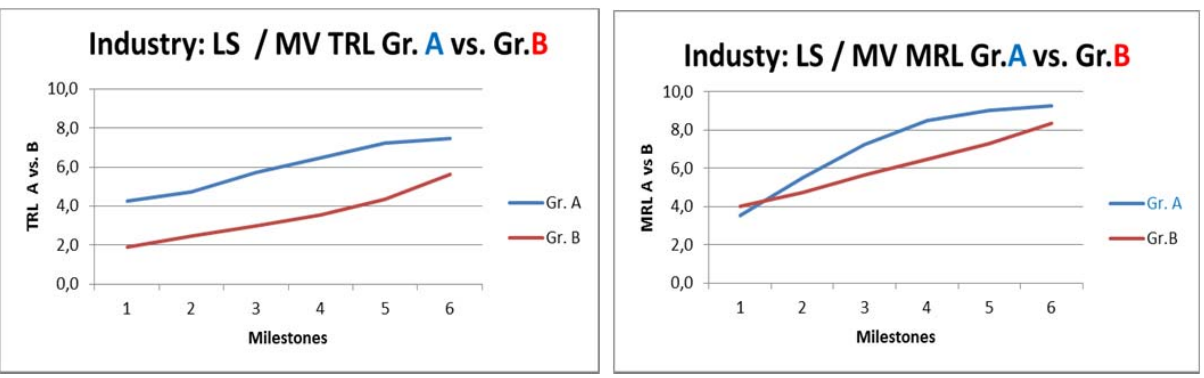
Difference in Incubation Process A + B Industry : ICT

ICT: Gr.A: MV TRL vs MV MRL

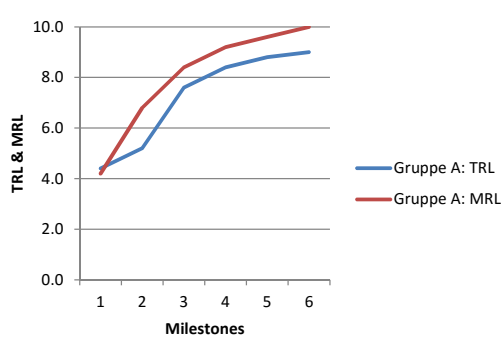

Longitudinal analysis
ICT: Gr.B: MW TRL vs MW MRL

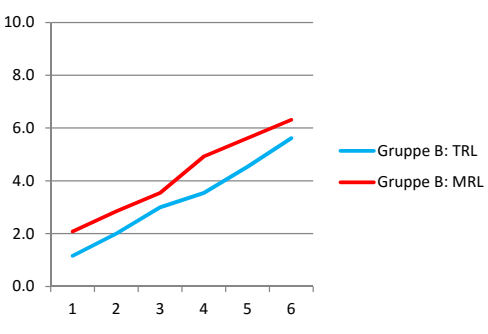

\section{Difference in Incubation Process A + B}

\section{Industry : ICT}

Industry ICT - MV TRL A vs. B

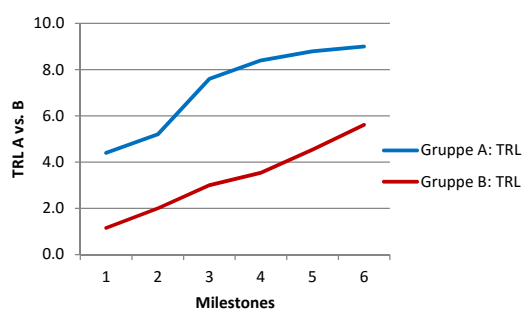

Industry ICT- MV MRL A vs. B

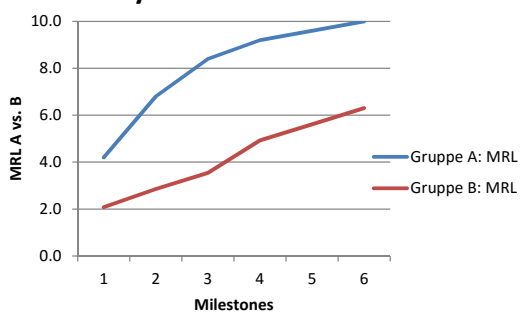

Longitudinal analysis 
Difference in Incubation Process A + B Industry : ENV

ENV: Gr. A: MV TRL vs. MV MRL
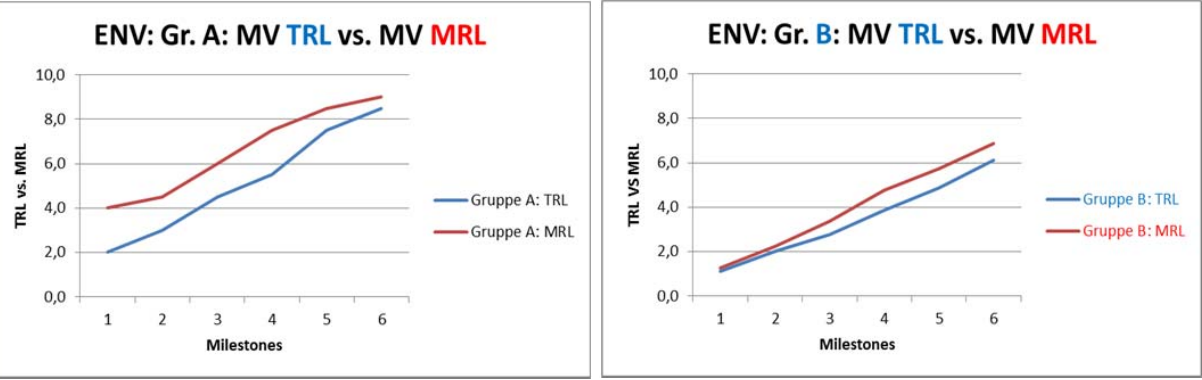

Longitudinal analysis

\section{Difference in Incubation Process A + B}

\section{Industry : ENV}

ENV Gr. A MW TRL vs. Gr. B MW TRL

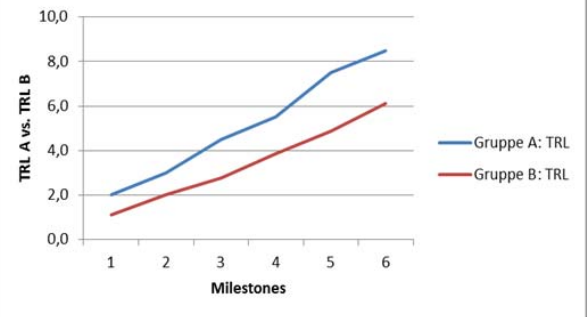

ENV Gr. A MW MRL vs. Gr. B MW MRL

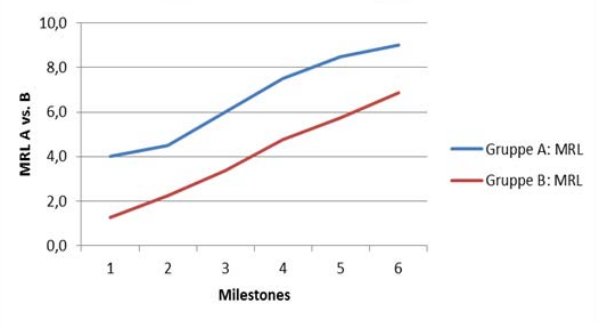

Longitudinal analysis 
Difference in Incubation Process A and B

- OTHer Technologies:

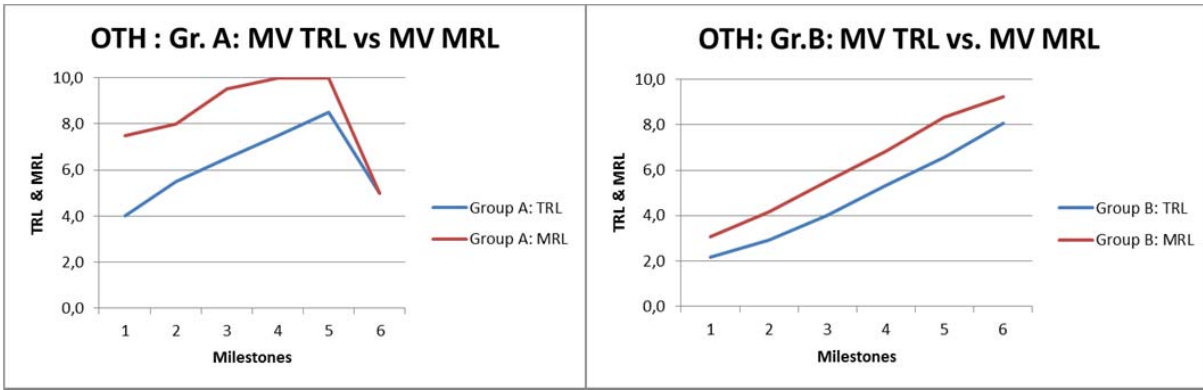

Longitudinal analysis

\section{Difference in Incubation Process A and B}

- OTHer Technologies:
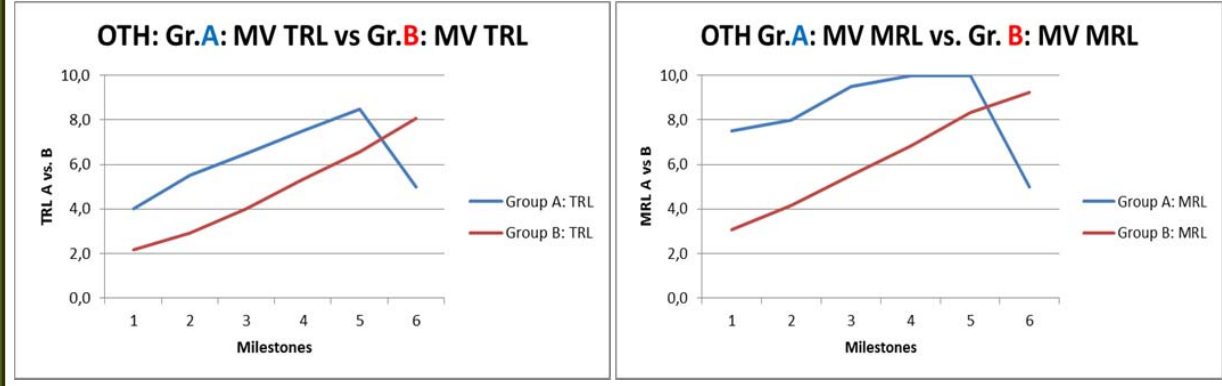

Longitudinal analysis 
Longitudinal Analysis:

Overall Results

\section{APPENDIX H}

\section{Difference in Incubation A and B}

- All Industries along milestones:

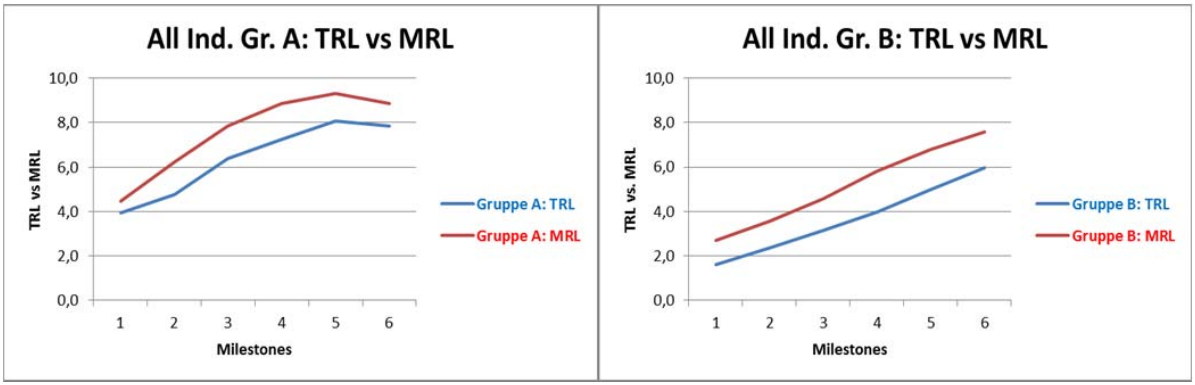

Longitudinal analysis 


\section{Difference in Incubation A and B in terms of TRL} all 4 industries

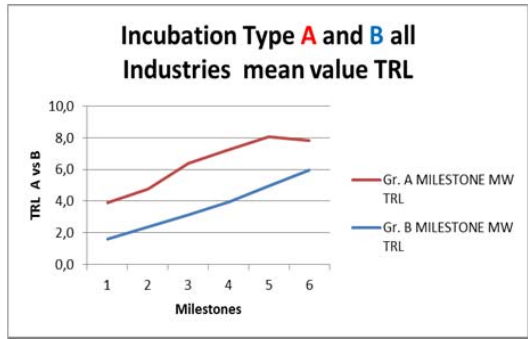

Longitudinal analysis

\begin{tabular}{|l|l|r|r|r|r|r|r|}
\hline & & \multicolumn{6}{|c|}{ TRL Difference between Incubation process } \\
\hline & Parameter & \multicolumn{5}{|c|}{ Type A and B } \\
\hline & Milestones & T-MS1 & T-MS2 & T-MS3 & T-MS4 & T-MS5 & T-MS6 \\
\hline Life Science & D3 LS TRL (A-B) & 2,34 & 2,30 & 2,75 & 2,95 & 2,89 & 1,86 \\
\hline ICT & D3 ICT TRL (A-B) & 3,25 & 3,20 & 4,60 & 3,06 & 2,46 & 1,58 \\
\hline Environment & D3 ENV TRL (A-B) & 0,88 & 1,00 & 1,75 & 1,63 & 2,63 & 2,38 \\
\hline Other & D3 OTH TRL (A-B) & 1,83 & 2,58 & 2,50 & 2,17 & 1,92 & $-3,08$ \\
\hline All & D3= ALL TRL(A-B) & 2,31 & 2,41 & 3,25 & 3,28 & 3,10 & 1,87 \\
\hline
\end{tabular}

\section{Difference in Incubation $\mathrm{A}$ and $\mathrm{B}$ in terms of $\mathrm{MRL}$} all 4 industries

\begin{tabular}{|l|l|r|r|r|r|r|r|}
\hline \multicolumn{7}{|l|}{$\begin{array}{l}\text { Incubation Type A and B all } \\
\text { Industries mean value MRL }\end{array}$} \\
\hline
\end{tabular}




\section{TRL and MRL along Incubation Milestones for all Industries}

- All Industries: (57 Start Ups, 4 industries)

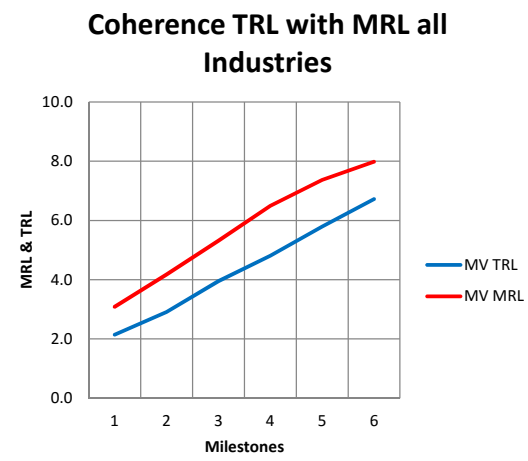

\section{TRL and MRL along Incubation Milestones for all Industries}

- All Industries:
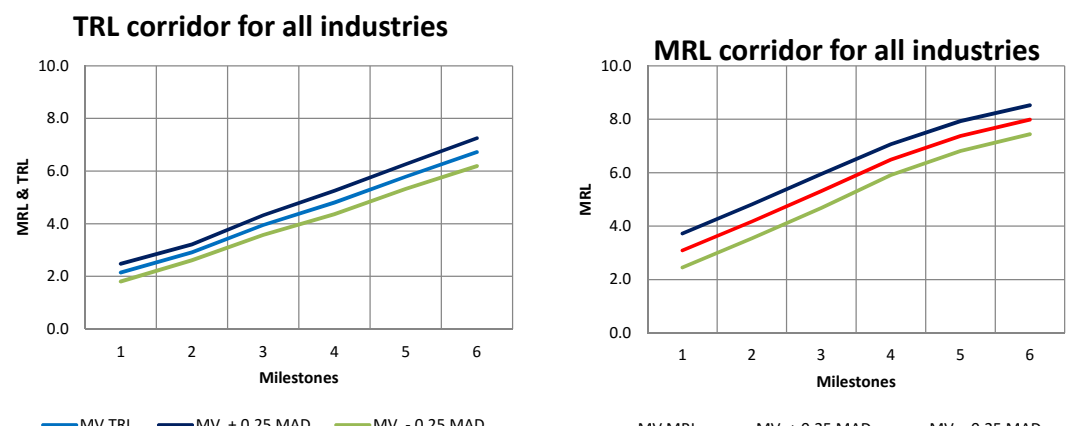

$\longrightarrow$ MV TRL $\longrightarrow$ MV + 0,25 MAD $\longrightarrow$ MV - 0,25 MAD

-MVMRL $-\mathrm{MV}+0,25 \mathrm{MAD}=\mathrm{MV}-0,25 \mathrm{MAD}$ 